\title{
The Influencing Effect Of Slogans In Segment Of Children
}

\section{Robert Sandor Szucs, Associate Prof., PhD}

College of Szolnok, Commerce,

Marketing and International Business Department, Szolnok, Hungary

doi: 10.19044/esj.2016.v12n16p24 URL:http://dx.doi.org/10.19044/esj.2016.v12n16p24

\begin{abstract}
Nowadays children face lots of slogans every single day. A good slogan generates feelings. Of course these feelings, brand names and slogans can be placed in mind of children by marketing experts. The remember rate of slogans is shockingly high, higher than is case of their parents. We can state that well-placed slogans play a very important role in influencing of children. All of these contribute to the development of brand loyalty, which if it develops during childhood - can last an entire lifetime. My primary research (sample size is 1222 children) shows the remember rate of slogans and brand names in case of different foods with high level of fat-, sugarand/or salt content.
\end{abstract}

Keywords: Children, slogan, trade mark, marketing, advertisement

\section{Introduction}

In the $21^{\text {st }}$ century children became the No. 1 target audience of adverts. Masses of companies with the help of classic adverts (and also by applying new and creative tools) try to convince this segment by exploiting their lack of experience and by no means fully developed system of preference. The impact is further triggered by the fact that nowadays children are often watching television programmes without the presence of their parents, in many cases on their own devices located in their room without any control measures. The target group of children and adolescents is extremely receptive to anything new, especially if all these new things are offered to them by using new, colourful and loud tools and devices, if possible in a simple manner. Of course the companies are also well aware of the above and they target in large quantities an age group without income, which can be very easily influenced. 


\section{Influencing of children}

ÚJVÁRI M. (2007) provided an excellent summary about the essence of slogans in the below few lines: „Slogan is a collocation, which placed in an advert wishes to achieve a strong recall impact by focusing on the essence, main message of a company, brand, product, political party or promotion. A good slogan sticks in people's minds. This can be achieved in two ways: on the one hand by huge amounts of repetition in various adverts - written or spoken or both; on the other hand by a collocation referring to the promoted company or product. Majority of the slogans bear minimum value. They are not unique; they can be easily interchanged/replaced by a slogan of any other company, brand, product or political party. They only gain value when they have been repeated for many years to the consumers."

Frequent repetition of a slogan establishes its true influencing power. They represent outstanding influencing power in the case of a segment, whereby the representatives of the segment show a positive attitude towards the adverts, they like them and they find them entertaining. The impact is further triggered by the high number of viewing hours spent on watching adverts (for example on television), and also by the fact that the members of the segment are unable to individual opinion formation, the members of the segment have no established system of preference. The group based on the description can be easily identified: we are talking about the age group of children. The key to the successfulness of the slogan lies in two factors:

- $\quad$ amount of time spent on watching television and

- $\quad$ the extent of the responsiveness of the children.

I would like to demonstrate The shaping of time spent on watching television based on the data published by AGB Nielsen Media Research. According to their research in 2013 the total population spent an average of 4 hours 46 minutes, namely 286 minutes in front of the television every day. The average duration spent in front of the television by people aged under 18 increased from 3 hours 11 minutes to 3 hours 22 minutes, while the age group of 18 to 49 years increased to 4 hours 1 minute from the year 2012 to 2013. People aged above 50 spent an average duration of 6 hours and 10 minutes in front of the television, 5minutes less than in 2012. In 2013 by taking into consideration the entire population above the age of 4 , on average 7.1 million people turned on their televisions at least for one minute, out of them 6.7 million people saw at least one advert. The average advert watching duration per capita/per day is 23 minutes; this represents 8 percent of the total television watching duration. A viewer saw an average amount of 78 adverts (AGB Nielsen, 2014). These are shockingly high numbers.

Multiple authors inspected The extent of the responsiveness of children. Piaget and Coffey et al. took the age as a basis for the definition. In their research they mention the period from ages 3 to 7 as an operating 
period. This is the age when children start to talk. Children by the age of 6 obtain a vocabulary including 8 to 14.000 words. The three most frequently expressed words are the following: "I... want ...that!” Their intelligence and cognitive skills go through quick development, but they are far from fully developed. This period is characterised by one-dimensional thinking, namely the absence of exact overview skills and the ability of understanding. As a result, children are characterised by gullibility in this period, they treat the information given to them (such as information broadcasted via adverts) as fact. It is easy to acknowledge that in this period the simple, quickly and easily understandable slogans have huge impact on these children. The next period of the concrete operating period (ages 7 to 11). In this period children are characterised by thinking. Brands are obvious for the children; the fundamental brand preferences are already established. It can be easily exploited that for children the brand and product mean exactly the same thing. They do not feel the difference, which makes them especially vulnerable. Children adhere in many cases not to the product, but to the brand. The decision of children is significantly influenced by colours, film/cartoon characters and logos. Children can be easily influenced by the tool of so-called brand licensing, namely by placing characters on the product or sold together with the product. The main thing is again that children easily remember them, which also true for slogans. As a result of the above children from the age of 7 , or even from the age of 5 ask for/demand certain branded products. (Piaget, 1966, 1999; Coffey et al., 2006)

The impact of the two factors can be summarised as follows. The child sits in front of the television and receives advertising messages by the advert blocks interrupting the television program, which most likely will be ignored by the people living together with the child. Therefore we cannot just simply not mention the adverts, as within a modern consumer society everyone is exposed to nearly constant advertising impact. Children are also no exception. (Simay, 2009). It is also a fact that children over the age of 3 recognise brands and the establishment of brand loyalty may already start from the age of 2 (Fischer et al., 1991, McNeal, 1992). According to Vekerdy (2000) the brand loyalty established until the age of 5 is permanent and may stay with the person during his/her entire life. The brand loyalty of teenagers is rhapsodic and in many cases hysteric. The American Psychological Association (APA) established a separate commission to investigate the impact of commercial adverts on children. Their findings showed that children under the ages of four and five are unable to distinguish between the adverts showed in the program from and the other programs. They are unable to recognise that people are trying to sell them things (Comstock, 1991.) All the above is further increased by the goal of the 
marketing focused on children, namely that children are able to identify and differentiate the products based on brand/logos as soon as possible. In brackets we need to add that slogans are simple and excellent tools for the achievement of the above, which helps children to position the product/brand. It is a fact that a child aged 2 has his/her own ideas about brands, while children aged 2 to 6 are able to clearly recognise and identify the most known brands by name, packaging or logo (Dersheid, 1996; Macklin, 1996). Children aged 5 to 8 are able to list several brands among the products aimed at children (McNeal, 1992). According to Látos (2005) children aged five are able to recognise 20 to 30 products based on the tune of the advert and logo, which is complemented by the nagging factor related to the obtainment of the desired product (Rust, 1993). Further surveys showed that 20 percent of children aged 3 already adhere to certain brands and they influence their parents in making the purchase. (Látos, 2005). By drawing attention to the standpoint of Linn (2008) all this happens in a way that majority of the adverts aimed at the young generation are food items, rich in energy but low in nutritional value. (Linn, 2008) Out of the yearly 40.000 adverts viewed, an average child watches 10.0000 food related adverts, out of which $90 \%$ advertises sugary drinks, sweets, corn flakes and fast food meals. By using the words of Brownell the extent of influencing the children is "unfair” (Spurlock, 2004).

In the reflection of the above direct and indirect data, it is clear to what extent is a well-formed slogan able to nestle in the heads of children. I would like to add that - as a deficiency of the specialised literature- we cannot or hardly can find specific numerical data about the efficiency of slogans and the ability of recalling them. In the works of Barta and Szücs (2016), the authors throw a light on the recall rates of slogans. In the frame of their research they have mentioned slogans to children related to food industry brand names, and they "tested" their recall ability by using the focus group method. (Children had to link the slogans with the correct brand name). There were 10 slogans and 10 brand names used during the task. The task included the correct matching of slogans and brand names, namely not spontaneous recall ability was measured. Out of the total children of 5x3 (15 in total) participating at the focus group research 12 children identified without a mistake all slogans of the given brands. The ratio of successful answers is shockingly high, thus I think it was necessary to accomplish a research with large number of samples in a way that the qualitative research method was slightly transformed into a quantitative one, by not losing the qualitative character. 


\section{Material and methodology}

I performed a primary research based on the secondary information. The goal of the research was to inspect the attitude of children towards slogans/brands/adverts, with special respect to the extent children are able to recall the exact brand name of the product based on the heard slogan. Numerous authors point out the fact, that children and adolescents already from a very early age adhere to brands, brand names, but only a few people investigate the spontaneous recall ability of brand names based on the heard slogans; namely if a child hears a slogan, is the child able to recall which brands slogan has he/she heard? In the current phase of my research I would like to find out more about the followings: how effective is the marketing activity of food manufacturers within the child segment, how much is the corporate marketing activity (especially slogans) able to nestle itself in the consciousness of children. The main idea behind the research is that the interviewer mentions slogans related to food industry products to children subject to the survey (verbal polling method), and then requests the child to tell the interviewer (without any help) that the heard slogan is related to which brand (spontaneous recall). In the frame of the research the following slogans were mentioned, correct answers are indicated in brackets:

- "Drink one more glass and blame it on the bunny.”(Nesquik)

- Pöttyös is the real one.” (Pöttyös Túró Rudi)

- "The mind boggles if you eat me” (Cheetos)

- "If you need a little energy" (Sport chocolate bar)

- Always a hit between main courses” (Kinder milky bar)

- "Dare to be gentle" (Milka)

- "On the Coke side of life” (Coca-Cola)

- "Energy until lunchtime” (Belvita JóReggelt)

- "Ugly and delicious” (Chokito)

- "Life at us is more and more milky" (Mizo)

- "Fruity juice, healthy, fully of vitamins" (Kubu)

- "The more chocolate, the more ....." (Boci)

- $\quad$ "Kinder ....... from the fridge" (Pingui).

A total number of 1222 children, aged between six and eleven, participated at the research. The interviews took place with the approval of the parents. Due to the ages of the children (absence of writing and reading skills) personal interviews proved to be the most accomplishable solution, by using simple methods tailored to the ages of the children. 618 girls and 604 boys participated at the research, this shows a $50.6 \%$ and $49.4 \%$ distribution of genders. With respect to the age groups of the sample even distribution was detected, 10 to $13 \%$ belongs to each age group. None of the age groups are over- or under represented within the sample. The average sample age supports this statement (the average age within the sample is 9.96 years). 
$60.1 \%$ of the children live in towns, $22.8 \%$ in villages, $15.1 \%$ at a county headquarter and $2 \%$ in the capital. The place of residence of the interviewed child is a significant factor in the analysis (which has been previously proved on many occasions during my previous researches, Szücs 2011). The interviewed children came from 14 counties of Hungary, out of which the most dominant counties included Jász-Nagykun-Szolnok County, Pest County, Bács-Kiskun County, Békés and Csongrád County. The data was collected between 31 $1^{\text {st }}$ October and $2^{\text {nd }}$ December 2015.

\section{Results}

During the research it was stated that the youngest children find the adverts very entertaining and they show positive attitude towards the adverts. My research numerically proves the statements made by the secondary specialised literature. This positive attitude however with the elapse of time, aging, continuously loses its intensity. In order to investigate the entertaining ability/factor of adverts I have requested the interviewers to ask children about the followings: how much do they like, how much do they find commercial adverts entertaining. The interviewers quantified the answers of the children by using the Likert scale (5 grades), whereby 1 meant total rejection in terms of the entertaining ability of adverts and 5 meant maximum entertaining ability, namely the most positive attitude. The law of great averages, the number of the 1222 interviewed children ensure the exclusion of subjectivity on the side of the interviewer, and/or the description of generally worded trends. The assessment of the positive attitudes towards adverts is supported by the 4 and 5 grade values of the Likert scale; these values clearly prove a positive attitude. The ratio of positive attitude towards adverts ( 4 and 5 values) is demonstrated by the below Figure 1 .

Figure 1. Rate of positive attitude presented to ads depending on age

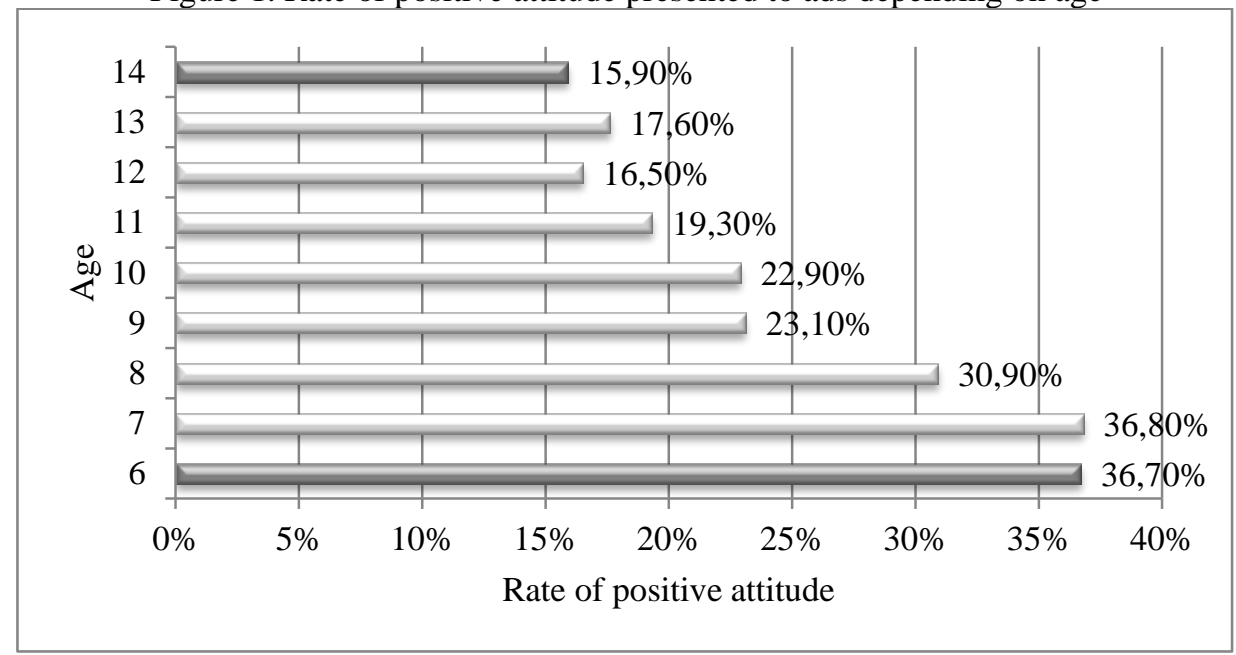

Source: own research, 2016 
The positive attitude presented towards adverts is extremely important, because the slogan indicated in the advert reaches the children subject to influencing via the advert tool itself; thus the opinion about the advertising tool is very important. The above Figure 1 demonstrates well that the youngest children are the most responsive to advertising messages; they embody the most the dream of marketing experts, namely positive attitude in relation to adverts. By the progress of their age the intensity of positive attitude clearly moderates.

It can be accepted as a general proposition that the positive attitude towards adverts supports the intensification/deepening of the slogan in the mind. As a result of the further parts of the research I have got to the conclusion that the members of the interviewed group (aged between 8 and 14) were able to recall the brand names based on the slogans heard in the adverts at a very high rate. The easiest way to measure this is the ratio of correct answers. An answer is correct, if the child is able to clearly, correctly and accurately mention the correct brand name after listening to the slogan. The answers of the children were considered correct if they were entirely correct after listening to the slogan ("some kind of coke", "some kind of milk bar", "some kind of Kinder" were not considered correct answers). In the case of certain slogans the ratio of correct and incorrect answers is measurable, furthermore also the lack of answer can also be measured ("I don't know, I have no idea"). The statement indicating that the children are able to recall the brand names of products based on the heard slogan namely in total the ratio of correct answers is considered higher- is not that simple phenomena. The statement is modulated by multiple factors.

As a result of the research it has been stated that the gender of the interviewed person does not influence the ratio of correct answers. Children gave correct or incorrect answers independently from their gender. After the assessment of the ratio of correct and incorrect answers based on genders we have experienced only a decimal difference (in many cases less than that). The Cramer association coefficient referring to the gender of the interviewed children and the correctness of the given answers in the case of various brand names was ranging between 0.02 and 0.06 , which indicator perfectly proves the above indicated information (namely that they are practically independent from each other). We have come to similar conclusion with respect to the place of residence (township, village, town, county seat, capital). The place of residence has no impact on the ratio of correct answers. Based on the Cramer association coefficient an independent relation is stated between the place of residence of the interviewed children and the correctness of the answers $(\mathrm{C}=$ =ranges between 0.04 and 0.08 depending on the product). 
Age plays a significant role in the formation of the ratio of correct answers. The higher the age is, the higher proportion of the correct answers we get. As a most significant change we can outline, that the identification ratio of the Coca-Cola slogan within the age group of 6 was "only" at 50.4\%, while the age group of 13 showed a $90.2 \%$ identification ratio. In the case of various brands this change showed the followings:

- $\quad$ In the case of Nesquik from $40.5 \%$ to $55.3 \%$,

- $\quad$ Pöttyös from $87.0 \%$ to $99.2 \%$,

- $\quad$ Cheetos from $14.0 \%$ to $38.8 \%$,

- $\quad$ Sport chocolate bar $16.3 \%$ to $42.4 \%$,

- $\quad$ Kinder milky bar from $20.2 \%$ to $37.4 \%$,

- $\quad$ Milka from $14.5 \%$ to $43.9 \%$,

- $\quad$ Belvita JóReggelt from 34.4\% to $74.8 \%$,

- $\quad$ Chokito from $11.5 \%$ to $16.5 \%$,

- $\quad$ Mizo from $9.9 \%$ to $24.2 \%$,

- $\quad$ and in the case of Boci the ratio of correct answers increased from $46.0 \%$ to $59 \%$.

In the case of two products the ratio of correct answers showed a different pattern deviating from the above described trend:

- $\quad$ In the case of Kubu a decline from $37.4 \%$ to 30 to $32 \%$ was detected. In absence of further investigation this concludes that the product is preferred the most by younger children (high involvement).

- In the case of Kinder Pingui the ratio of correct answers is a bit hectic. The highest ratio was detected in the case of the age group of 6 to 7 (48 to 50\%), which with the advancement of the age reduces (to $36.6 \%$ ) and further increases (to the value of 42 to $48 \%$ ).

It is also necessary to note (disregarding the above mentioned two exceptions) that by the advancement of the age the ratio of correct answers is growing, however this growth takes place not in a linear ratio, but much rather gradually. It can be detected that the increase of the ratio of correct answers within the inspected age groups takes place typically in two steps. The first increase in the ratio of correct answers takes place in the age group of 8 to 9 years, while the second significant increase is identified within the age group of 12 to 13 year olds. It is also important to note that the recall of the "slightly left behind" Chokito brand name was difficult, by the reduction of advertising costs the reputation of the slogan promptly reduced, people forgot about it.

It was also possible to carry out a deeper statistical analysis of the data, and I have chosen cluster analysis (K-means Cluster) as a tool. The segmentation criterion resulting from the previously detailed argumentation, besides the criterion used for the measurement of the cognitive component (how much are the slogans known) the affective, emotional component and 
the age of the interviewed persons were also involved as important demographical factor. The below Table 1 demonstrates the result of segmentation.

Table1: Ratio of correct answers of different brand names according to clusters

\begin{tabular}{|c|c|c|c|c|c|c|}
\hline $\begin{array}{l}\text { Segment } \\
\text { Statements }\end{array}$ & $\begin{array}{c}1^{\text {st }} \\
\text { segment }\end{array}$ & $2^{\text {nd }}$ & $\begin{array}{c}3^{\text {rd }} \\
\text { segment }\end{array}$ & $\begin{array}{c}4^{\text {th }} \\
\text { segment }\end{array}$ & $\begin{array}{l}\text { Average } \\
\text { value }\end{array}$ & F-rate \\
\hline How much do you like ads? $*$ & 2.6 & 3.2 & 2.2 & 2.7 & 2.7 & 45.404 \\
\hline $\begin{array}{c}\text { Proportion of right answers - } \\
\text { Nesquik (\%) }\end{array}$ & 20.6 & 76.0 & 17.2 & 85.0 & 47.5 & 238.232 \\
\hline $\begin{array}{c}\text { Proportion of right answers - } \\
\text { Pöttyös Túrórudi (\%) }\end{array}$ & 87.0 & 98.4 & 97.4 & 99.2 & 95.2 & 24.926 \\
\hline $\begin{array}{c}\text { Proportion of right answers - } \\
\text { Cheetos (\%) }\end{array}$ & 6.1 & 34.4 & 11.3 & 45.1 & 22.9 & 92.659 \\
\hline $\begin{array}{l}\text { Proportion of right answers - } \\
\text { Sport chocolate bar (\%) }\end{array}$ & 11.8 & 39.0 & 15.9 & 56.9 & 29.3 & 79.914 \\
\hline $\begin{array}{c}\text { Proportion of right answers - } \\
\text { Kinder milky bar (\%) }\end{array}$ & 10.9 & 37.3 & 19.4 & 49.0 & 27.9 & 80.480 \\
\hline $\begin{array}{c}\text { Proportion of right answers - } \\
\text { Milka (\%) }\end{array}$ & 7.9 & 40.6 & 14.6 & 60.9 & 29.2 & 124.277 \\
\hline $\begin{array}{c}\text { Proportion of right answers - } \\
\text { Coca-Cola (\%) }\end{array}$ & 41.5 & 84.4 & 76.4 & 92.5 & 72.3 & 100.607 \\
\hline $\begin{array}{l}\text { Proportion of right answers - } \\
\text { Belvita JóReggelt (\%) }\end{array}$ & 23.3 & 70.8 & 56.3 & 85.0 & 57.0 & 114.365 \\
\hline $\begin{array}{c}\text { Proportion of right answers - } \\
\text { Chokito (\%) }\end{array}$ & 3.0 & 24.7 & 2.9 & 29.6 & 14.2 & 58.339 \\
\hline $\begin{array}{c}\text { Proportion of right answers - } \\
\text { Mizo (\%) }\end{array}$ & 2.1 & 21.8 & 5.5 & 33.2 & 14.6 & 49.599 \\
\hline $\begin{array}{c}\text { Proportion of right answers - } \\
\text { Kubu (\%) }\end{array}$ & 24.2 & 48.1 & 14.6 & 50.6 & 33.4 & 64.842 \\
\hline $\begin{array}{c}\text { Proportion of right answers - } \\
\text { Boci (\%) }\end{array}$ & 29.1 & 73.7 & 26.9 & 83.4 & 51.4 & 135.365 \\
\hline $\begin{array}{c}\text { Proportion of right answers - } \\
\text { Kinder Pingui (\%) }\end{array}$ & 35.5 & 52.9 & 36.9 & 51.4 & 43.7 & 17.629 \\
\hline Typical age of respondent (year) & 7.4 & 8.5 & 12.0 & 12.8 & 10.0 & 1448.037 \\
\hline Proportion of segment (\%) & 27.5 & 25.7 & 25.8 & 21.1 & - & - \\
\hline
\end{tabular}

* 5 point Likert scale where 1 = I don't like it absolutely, 5 = I like it totally Source: own research, 2016.

The accuracy and correctness of the analysis is excellently proved by the fact that in the case of all variables I have obtained reliable values (Sig.=0,000). The F-rate values prove the correctness of the variables and the weight of the segmentation criterion. During the cluster analysis 4 established groups (segments) meant an accurate solution, and the opinion and level of knowledge of these groups can be clearly distinguished. It can be seen clearly that based on the established segments two typical categories can be separated:

- $\quad$ The representatives of the $1^{\text {st }}$ category include children, who are able to recall brand names after hearing the slogans at a level below average. This group is made up by the members of the $1^{\text {st }}$ and $3^{\text {rd }}$ segment. There is 
significant difference detected between the age groups. While the $1^{\text {st }}$ segment is typically made up by the youngest children (average age within the segment is 7.4 years) paired up with the lowest recall ability, the members of the $3^{\text {rd }}$ segment can be characterised by higher age (12.0 years). The additional knowledge due to the higher age can also be seen clearly, which is at its present, increased stadium is at a level below average. Members of the $1^{\text {st }}$ segment are doubtful and members of the $3^{\text {rd }}$ group are rejective members in short.

The representatives of the second category include children, who are able to recall brand names after hearing the slogans at a level above average. This group is made up by the members of the $2^{\text {nd }}$ and $4^{\text {th }}$ segment. There is also a significant difference detected between the age groups. While the $2^{\text {nd }}$ segment is typically made up by younger children (average age within the segment is 8.5 years), the members of the $4^{\text {th }}$ segment can be characterised by higher age (12.8 years). The additional knowledge due to the higher age can also be seen clearly. It is important to that the members of the curious $2^{\text {nd }}$ segment were able to give correct answers at a higher rate, than the members of the $3^{\text {rd }}$ segment, who are older, but less prone to marketing. Members of the $2^{\text {nd }}$ segment can be influenced, while the members of the $4^{\text {th }}$ segment are the convinced members in short.

In the case of both categories the life path of children can also be clearly seen. At the earliest age the unconvinced $1^{\text {st }}$ segment members later on become the rejective members of the $3^{\text {rd }}$ segment, while the influencable $2^{\text {nd }}$ segment members by the advancement of the age become the members of the $4^{\text {th }}$ segment, namely they are the convinced ones. It is important to note that the members of the $4^{\text {th }}$ segment are able to recall the brand names based on the heard slogan with a shocking accuracy. This is a true advert-loving segment, which has been fully saturated by marketing.

It would be really interesting to assess the factors having an impact on which segment (1 or 2 ) the given child starts his/her "career" in the above reasoning, because this have an impact on his/her future. In terms of marketing this future is equivalent to the extent of the child's future ability to be influenced by the tools of marketing. Belonging to the $3^{\text {rd }}$ and $4^{\text {th }}$ segments is a kind of consequence, namely the consequence of the roots and the accomplishment of previously fixed attitudes. The role of the family is presumably important, furthermore other reference persons, the viewed behaviour patterns, the time spent on watching television and the personality of the child are also of importance. The mapping of these impacts could be the topic of a later, qualitative study.

As a further survey result the accumulation of factors established during the discriminant analysis was accomplished. In the frame of the discriminant analysis the SPSS establishes 2 functions, which are elaborated 
by the accumulation of the previously defined factors. With its help the established segments (clusters) become also graphically visualisable in the dimension of previously established factors, showing and presenting its correctness. The below Figure 2 demonstrates the depiction of the segments and their spatial location compared to each other based on the above functions.

Figure 2. Cluster centroid of different segments

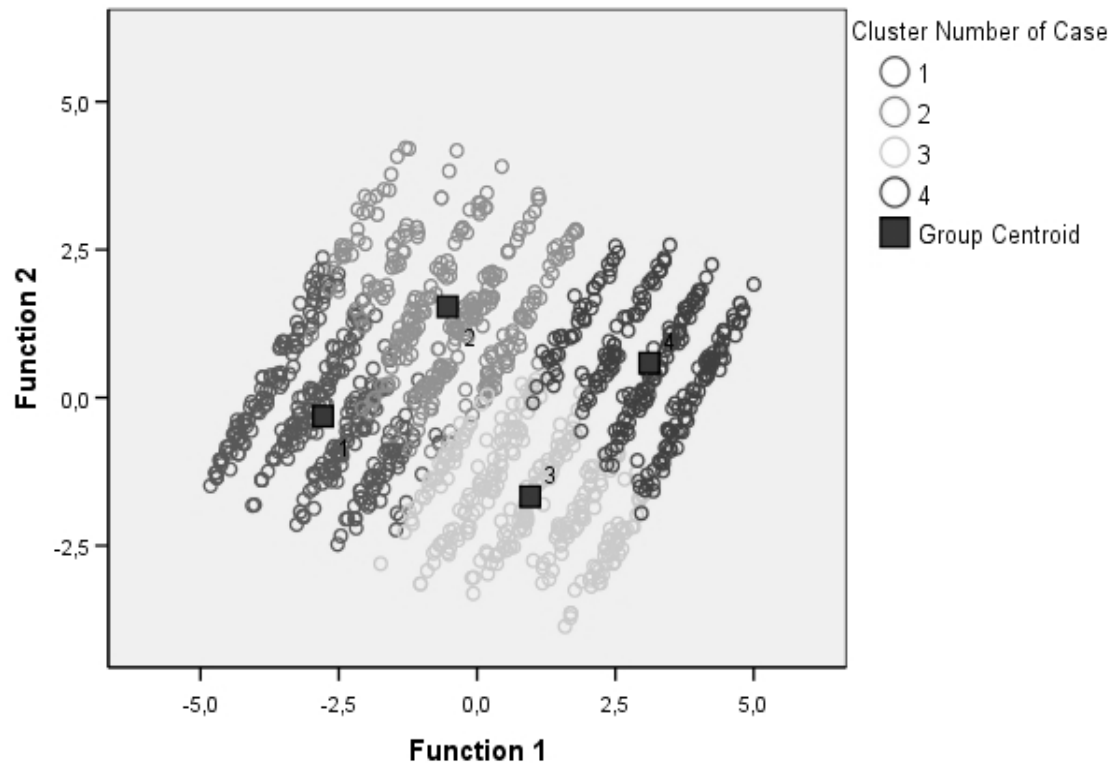

The discriminant analysis pointed out the importance of the influencing power of age, as the age of the interviewed persons explains total variance ( $1^{\text {st }}$ function) to an extent of $75 \%$. The above chart shoes that the segments create very well distinguishable groups. The chart shows very well the difference between the segments in terms of their knowledge. The accuracy of the distribution is proved by the fact that $95 \%$ of the interviewed persons were classified under any of the groups.

\section{Summary}

During my researches I examined the effect of marketing communication activity on young people, especially the effectiveness/identification ratio of slogans. I measured the influencing effect of companies' marketing activity, attitude directions and intensity towards commercials. We can state that slogans can reach and influence the youngest children. A good slogan can help you achieve your goals (improve the brand awareness, loyalty, indirectly realize profit, etc.), but it does not make miracles. Of course there is a considerable cost if the company would like to have a well-known slogan. The success is not free. The key success factors of the slogan can be found in simplicity, clarity, uniqueness and in time and 
repetition. The slogan is like a flower. If you are not caring for the slogan of the product it will lose force or vitality, become diminished and wane. I think not only the brand loyalty but awareness of a good (repeated) slogan established until the age of 14 is permanent and may stay with the person during his/her entire life.

\section{References:}

AGB NIELSEN (2014): A tévéképernyőt bámulva tölti a szabadidejét az átlag magyar, http://www.mfor.hu/cikkek/vallalatok/A_tevekepernyot_bamulva_tolti_a_sz abadidejet_az_atlag_magyar.html,

BARTA B., SZÜCS R. S. (2016): Reklámozás, szlogen és szuperhősök - A gyermekek meggyőzésének eszközei, Táplálkozásmarketing, 2015. II. évfolyam 2. szám, p. $47-58$.

COFFEY T. J.; SIEGEL D. L., LIVINGSTON G. (2006): Marketing to the new super consumer: mom \& kid. Paramount Market Publishing Inc., Ithaca. p.13-20

COMSTOCK G. (1991). Television and the American child. Academic Press Inc., p. 335

DERSHEID LE, KWON YH, FANG SR. (2006): Preschoolers' socialization as consumers of clothing and recognition of symbolism. Percept Mot Skill; 82: p. 1171-1181.

FISCHER P. M., SCHWARTZ M. P., RICHARDS J. W. JR., GOLDSTEIN A. O. (1991). Brand logo recognition by children aged 3 to 6 years: Mickey Mouse and Old Joe the Camel. Journal of the American Medical Association, 266, p. 3145 - 3148.

LÁTOS E. (2005): Gyerekek, marketing, pszichológia és etika összehangolható fogalmak?, Budapesti Gazdasági Főiskola, p. 18.

LINN S. (2008): Calories for Sale: Food Marketing to Children in the Twenty-First Century, The ANNALS of the American Academy of Political and Social Science, Vol. 615, No. 1, p 133-155

MACKLIN, M.C. (1996): Preschooler's learning of brand names from visual clues. Journal of Consumer Research 23(3): p. 251-261.

MCNEAL J. (1992). Kids as customers. NY:Lexington Books., ISBN 9780669276275, p. 272

PIAGET - INHELDER (1966): La psychologie de l'enfant. Paris, 1966, Presses Universitaires de France.) ISBN 9633796253 ISSN: 1518-1222, p 151.

PIAGET - INHELDER (1999): Gyermeklélektan, Budapest, Osiris, 1999, p. 140 
RUST, L. (1993): Observations - parents and children shopping together: A new approach to the qualitative analysis of observational data. Journal of Advertising Research (July/August): p. 65-70.

SIMAY A. E. (2009): A gyerek, mint fogyasztó, EuroAstra Internet Magazin, 2009/01/28, http://www.euroastra.info/node/22552

SPURLOCK M. (2004): Super Size Me, Documentary, Best Hollywood, Documentary, min. 100

SZÜCS R. S. (2011): A fiatalkorúak által fogyasztott néhány élelmiszeripari termék marketing és fogyasztóvédelmi szempontú vizsgálata, Debreceni Egyetem, Ihrig Károly Gazdálkodás- és Szervezéstudományok Doktori Iskola, http://hdl.handle.net/2437/103324, p. 1 - 197.

ÚJVÁRI M. (2006): Szlogenek: a jó szlogen, a vicces szlogen és a békebeli magyar szlogen, http://www.sikermarketing.hu/szlogenek-jo-szlogen-viccesszlogen-es-bekebeli-magyar-szlogen

VEKERDY T. (2000): Kérdezz! felelek... gyermekekről felnőtteknek, PARK Könyvkiadó Kft., ISBN: 9635305702, p. 358. 